\title{
The Nature of Knowledge in Composition and Literary Understanding: The Question of Specificity
}

\author{
Peter Smagorinsky \\ University of Oklahoma \\ Michael W. Smith \\ Rutgers University
}

\begin{abstract}
Psychologists have long debated the extent to which people transfer knowledge from context to context. This debate has emerged in the study of literacy where researchers of composition and literary understanding have begun to examine the extent to which different tasks require particular knowledge and the extent to which different interpretive communities require specific understandings. This article reviews issues related to transfer and knowledge specificity as articulated in psychology and then examines theory and research in composition and literary understanding which parallel the debate in psychology. The authors identify three positions that have emerged in literacy debates: the case for general knowledge, the case for task-specific knowledge, and the case for community-specific knowledge. Each position carries with it certain assumptions about learning and transfer, and each has clear implications for curriculum and instruction. The authors delineate the positions and the assumptions that drive them and detail their instructional consequences, arguing that researchers and teachers need an articulated understanding of their assumptions about knowledge and transfer in order to establish a clear and coherent relationship between theory and practice.
\end{abstract}

Whenever teachers instruct, they implicitly convey their beliefs about knowledge transfer. Teachers assume not only a certain knowledge base on the part of students but also an ability on the students' part to bring that knowledge to bear on new instructional situations. Furthermore, teachers make assumptions about the knowledge that students will transfer from new instruction to future learning experiences: They will learn from writing one composition how to write well on subsequent essays, they will learn from reading Gulliver's Travels how to understand other satires, and so on.

The questions that researchers of literacy investigate often concern knowledge transfer. Inquiries into language and literacy acquisition have investigated ways in which learners draw on prior knowledge as they read and write and, often, seek connections between the processes underlying the two (e.g., Irwin \& Doyle, 1992). The purpose of this article is to review the issue of knowledge transfer as it has been discussed generally in the literature of educational psychology and then to examine three positions relative to knowledge transfer that have emerged in studies of literacy

\footnotetext{
We thank a number of colleagues who took the time to provide thoughtful critiques of earlier versions of this manuscript: Deborah Brandt, Michael Carter, Roger Cherry, Stuart Greene, Jay Lemke, Wayne Otto, Brian White, Steve Witte, and the editors and anonymous reviewers of $R E R$.
} 


\section{Smagorinsky and Smith}

in the areas of composition and literary understanding: the case for general knowledge, the case for task-specific knowledge, and the case for community-specific knowledge. By situating themselves in reference to these positions, researchers and teachers can better articulate the principles that motivate their theory and practice.

\section{The Debate in Educational Psychology}

The debate about issues surrounding critical thinking illustrates the problems faced by theorists and researchers in composition and literary understanding. Among the most thorny and rancorously contended problems in critical thinking discussions is the extent to which learners can transfer general knowledge to particular situations. A recent exchange between Ennis $(1989,1990)$ and McPeck (1990) illustrates a central contention in the dispute. The arguments of each are complex and have occupied many years of their careers, but they might be summarized as follows: "[It] makes sense to talk about significant general critical thinking abilities and dispositions, that at least some are not trivially obvious, and that applying an ability in a variety of domains makes it a general ability" (Ennis, 1990, p. 16). In contrast, "[There] are almost as many different kinds of critical thinking as there are different kinds of things to think about. The criteria for applying and assessing critical thinking derive from the thing . . . discussed or thought about at the time" (McPeck, 1990, p. 10).

Their disagreement centers around some of the more vexing problems facing educational theorists and practitioners: To what extent is knowledge specific to particular situations? To what extent can learners transfer knowledge from one context to another? Can people learn general skills that help them to solve problems in a variety of fields? Do people exercise a "mental muscle" when they attempt to solve particular problems? These questions have motivated the debate over the value and appropriateness of school courses in subjects such as critical thinking, ethics, study skills, values clarification, composition, reading, and statistics, all of which purport to teach general abilities that one can transfer to a variety of domains. No conclusive evidence has emerged to validate or discredit any single perspective on the problem of how effectively people transfer general knowledge to particular situations.

Perkins and Salomon (1989) have provided an insightful analysis of the issue of general and specific knowledge as debated by psychologists. They illustrate the problem with the hypothetical example of whether or not a chess master would make a capable military leader. (Interestingly enough, we see a similar occupational transfer in common practice: the retired military general hired as a business executive or its educational corollary, the high school football coach who becomes an administrator.) Those who support the position of the transfer of general thinking skills would argue that certain strategic principles, such as controlling the center of the arena, should carry over from chess to war. Those arguing in favor of specific knowledge might counter that wars should be fought by soldiers who know the intricacies of the enterprise: General Custer learned all too well that control of the center of the conflict is a highly context-specific strategy.

Psychologists have come up with different answers to the question of the extent to which general knowledge is sufficient to solve particular problems. Polya (1954, 1957), for instance, identified a set of heuristics, such as breaking a problem into subproblems and using diagrams to represent a problem in different ways, as part of a 
repertoire of general problem-solving skills in math. Others have since questioned the strength of the broad applicability of these methods, concluding, as the debate is outlined by Perkins and Salomon (1989), that "the more general the method, the weaker the method" (p. 19). The conflict between the general and specific knowledge positions raises questions about how learners fare when employing their knowledge in new situations. In the afterglow of Operation Desert Storm, for instance, General Norman Schwartzkopf was reported to be a candidate for the chancellorship of at least one large state university-presumably due to his intelligence, foresight, organization, and leadership abilities. Those who questioned the wisdom of his appointment might have pointed to contextual factors such as faculty activism, student activism, lack of a clear chain of command, and so on which might weaken the leadership skills that a military officer relies on for authority.

Theorists and researchers in both composition and literary understanding have begun to debate issues similar to those argued by general learning theorists. Some scholars have argued that students should acquire general knowledge about writing and literary understanding that enables proficiency in all contexts. Others maintain that different types of tasks (i.e., writing an argument or interpreting ironic literature) require specialized knowledge that is not necessarily applicable to other types of tasks. A final group contends that even particular types of tasks require specific knowledge depending on the context of their application; Colomb (1988) calls these specialized areas communities, "with all the ideological, economic, political, material, linguistic, moral, and other determinants of communal life" (pp. 2-3). Successful performance within each community, he argues, requires particular knowledge "at every level of text structure, from syntax through global discourse structure" (p. 3).

Before we explore these positions, we should explain what we mean by knowledge. Often, knowledge is assumed to be, in the words of Dickens's Mr. McChoakumchild, "Fact, fact, fact!" We use the term here as it has been used in cognitive psychology to encompass the what, how, and when of learning. Knowledge in our conception includes:

1. Knowledge of content, which is not merely one's factual knowledge of information of the sort found in Hirsch's (1987) Cultural Literacy but is also knowledge of one's own personal experiences, of the implications of an approaching thunderhead, of the functions of the various buttons on one's computer keyboard, and so on-that is, knowledge that one can name.

2. Knowledge of form, which is the knowledge that enables one to distinguish one thing from another according to their features-such as, knowing how to distinguish an alligator from a crocodile, cool jazz from bebop, and so on.

Each of these two types of knowledge can include declarative and procedural knowledge. Declarative knowledge concerns what; one either does or does not know who the 14th president was, how an in medias res story structure begins, and so on. Procedural knowledge concerns how; one might be able to identify an in medias res opening in The Odyssey, but one does not know how to begin such a story oneself. (See Hillocks, 1986b, for an elaboration of this perspective on knowledge.)

3. Conditional knowledge (e.g., Paris, Lipson \& Wixson, 1983), which is the knowledge of when to apply knowledge of content or form. One might know how to exaggerate for a humorous effect, for instance, but conditional knowledge should inform one not to exaggerate when reporting research results. (See Alexander, Schallert, \& Hare, 1991, for a comprehensive review of knowledge terminology.) 
Our discussion of the nature of knowledge, then, considers the types of knowledge typically identified in debates about learning. At this point, we will outline the positions taken by theorists of composition and literary understanding regarding the necessity and sufficiency of general, task-specific, and community-specific knowledge. Three points before we begin: First, we are focusing on a specific kind of composing - the production of extended written discourse of the sort typically written and read in schools and in professional life-and a specific kind of reading-the reading of imaginative literature. Second, our discussion of knowledge does not include a discussion of grammatical knowledge because both readers and writers unquestionably transfer such basic knowledge from situation to situation. (See Hillocks \& Smith, 1991, for a discussion of instructional issues related to grammar.) Third, we are attempting to clarify and to illustrate the three positions we have identified, rather than to provide a comprehensive survey of literacy research informed by these positions. We have thus circumscribed the issues in order to make them manageable within the limitations of a single essay.

\section{Composition}

\section{The Argument for General Knowledge}

The assumption that general knowledge is sufficient for most composing needs has driven practice for many years. The primary instructional tool involving general composing knowledge has been the general expository model as outlined in books such as Warriner and Griffith's (1977) English Grammar and Composition: Complete Course, which Applebee (1986) describes as "the most widely used composition text today" (p. 95). This Heritage edition of Warriner and Griffith's, for instance, informed the secondary student that.

\footnotetext{
Most of the writing you are required to do in school-tests, reports, essays-is expository, and most of the writing you will do after you leave school will be of this kind.

No matter what you are writing about, the basic steps involved in writing are almost always the same. They should become so familiar that you will follow them habitually whenever you write. (p. 339)
}

The steps outlined by the text include selecting and limiting a topic, assembling materials, organizing and outlining ideas, writing a draft that follows a particular form (usually including five paragraphs), revising, and preparing a final draft.

Many might arch a skeptical eyebrow concerning the clairvoyance of Warriner and Griffith regarding the type of writing most people will produce both in and, particularly, beyond school. Although a staple of instructional practice for many years, the five-paragraph theme has fallen into disrepute among academics. The most scathing criticism comes from Emig (1971) in her famous fifty-star theme derogation in which she calls it an "essentially redundant form, devoid, or duplicating, of content in at least two of its five parts . . . the assumption [being] that freshman English is a monolith, rather than a hydra-headed monster . . ." (pp. 97-98). Emig was concerned that the form itself was incommodious to the many and various needs of writers and that the instructional emphasis was on product instead of process.

A final problem, and the one that we focus on in the present exposition, concerns the assumption about the extent to which people can transfer general knowledge, whether of product or of process, to novel situations. Warriner and Griffith's (1977) text and similar texts instructed for many years from the premise that one composi- 
tion is much like the next and that knowledge of a general text form will enable students to reproduce the single essential text structure successfully and abundantly. This assumption about the widespread applicability of the five-paragraph theme structure still influences many secondary teachers of our acquaintance who practice it both by choice and by department and school board mandate.

The assumption about the widespread applicability of general composing knowledge related to essay form affects current practice in other ways as well. "Style checker" computer programs, for instance, are produced by a number of companies, including the venerable Modern Language Association, suggesting the existence of both a strong market and an authoratative belief in the power of general knowledge. Such programs are designed to suggest areas of improvement for any composition submitted to them; they flag what they perceive as problems regardless of the rhetorical demands of particular pieces. These programs, in spite of their popularity, are routinely criticized for their assumptions about the general nature of composing knowledge. When evaluating the Gettysburg Address, for instance, they offer the predictably comical suggestion that the author should be more concise, subverting the unique rhetorical demands of Lincoln's oratory to the general prescription that writers should avoid being wordy.

Faith in the sufficiency of general knowledge of text structure is rare among the professoriate and has been replaced by a belief in general procedural knowledge that has begun to transform teaching and textbooks. One instructional tool for imparting general composing procedures is the heuristic, which is a general probe, usually in the form of a question, that points the writer towards some aspect of composing. Several researchers and theorists have investigated the use of heuristics as a general tool for improving writing. Larson (1968), for instance, proposed a plan for teaching rhetorical invention through the development of an extensive set of questions that writers might apply to their compositions. In the area of "Writing about Propositions" (p. 133), for example, he identified such questions as "What must be established for the reader before he will believe it?" and "To what line of reasoning is it apparently a conclusion?" (p. 133). Similarly, Odell (1976) has developed a set of general questions-such as, "contrast" (p. 80) questions: "In what ways is $X$ different from other things I know?" (p. 80). The sorts of heuristics developed by Larson and Odell have been studied by several researchers (Burns, 1980; Dutch, 1980; Ebbert, 1980; Lamberg, 1974; Odell, 1974; Young \& Koen, 1973) who have achieved mixed results regarding their effectiveness in improving writing, with the results often called into question by the studies' dubious means of control (i.e., confounding variables in the treatment design). Hillocks (1986a) nonetheless finds their promise "encouraging" (p. 180) and suggests that they be investigated further.

Despite their potential, heuristics have been supplanted in popularity by general procedures for producing texts that rely on nonlinear thinking such as brainstorming, clustering, and free writing. Among the foremost advocates of these nonlinear procedures has been Murray $(1980,1987)$, who refers to "the process approach to writing" (1987, p. 6) as consisting of five steps: collecting, focusing, ordering, developing, and clarifying. Writers can apply this general process to any composing problem and couple the five steps with general strategies such as free writing, brainstorming, and mapping. "Freewriting," maintains Murray, "is just as valuable a technique to use as a starting point for a term paper, a historical essay, or a review of scientific literature" (1987, p. 42). Free writing, he argues, is a fundamental tool for 


\section{Smagorinsky and Smith}

unearthing that which one has to express: It "makes writing easier by helping you with the root psychological or existential difficulty in writing: finding words in your head and putting them down on a blank piece of paper" (p. 14).

The most passionate proponent of general procedures undoubtedly has been Elbow (1973, 1981), who has written extensively and with considerable influence about the seemingly endless benefits of free writing. He describes two general writing procedures. One is the direct writing process, which he recommends "for tasks like memos, reports, somewhat difficult letters, or essays where I don't want to engage in much new thinking" (1981, p. 26). The direct writing process "is very simple. Just divide your available time in half. The first half is for fast writing without worrying about organization, language, correctness or precision. The second half is for revision" (p. 26).

The second process is the loop writing process:

For the first half, the voyage out, you do pieces of almost-freewriting during which you allow yourself to curve out into space-allow yourself, that is, to ignore or even forget exactly what your topic is. For the second half, the voyage home, you bend your efforts back into the gravitational field of your original topic as you select, organize and revise parts of what you produced during the voyage out. (p. 60)

He gives several quite disparate examples of possible applications of the loop process: a comparison/contrast of Freud and Jung, an analysis of the causes of the French Revolution, a report on levels of pollution of various chemicals in Puget Sound, an analysis of government expenditures for various kinds of armaments and defense, and a paper on abortion.

The assumption behind this conception of composing knowledge is that writing consists of a very few simple procedures that one develops and uses effectively through practice. "The voyage out" is serviceable regardless of particular navigational problems of the myriad tasks one endeavors or of the gravitational fields one enters; it will guide explorers through meteor showers, black holes, intense solar heat, and Klingon attacks with equal dexterity. The position holds that, while one might need particular content knowledge to write about Freud or the French Revolution, one's process in executing the tasks or approaching the topics needn't vary.

Murray's (1987) and Elbow's (1973) advocacy of free writing is largely impressionistic. Several experimental studies have investigated the method's effects on improving writing. Alloway, Carrol, Emig, King, Marcotrigiano, Smith, and Spicer (1979); Cummings (1981); Hilgers (1980); Olson and DiStefano (1976); and Wagner, Zemelman, and Malone-Trout (1981) achieved significant gains through treatments involving free writing, yet a great number of studies has found no significant improvement between treatments involving free writing and control treatments (Adams, 1971; Arthur, 1981; Baden, 1974; Davis, 1979; Delaney, 1980; Dreussi, 1976; Fox, 1980; Ganong, 1975; Gauntlett, 1978; Norwood, 1974; Reynolds, 1981; Walker, 1974; Witte \& Faigley, 1981). The body of experimental research may be questionable for a number of reasons. Newkirk (1987) points out that the bulk of the studies has not been published in refereed journals, suggesting a general lack of rigor. Hillocks (1986a) identifies flaws in the design of some studies, such as a lack of pretests. He also points out that researchers have constructed varying definitions of free writing in the design of the different studies, thus making the procedure and its effects difficult to pinpoint. Furthermore, at times, treatments in the control groups were not explicated; at other times, they were identified only as traditional instruc- 
tion-presumably, grammar instruction, the study of model essays, and so onresulting in the sort of apples and oranges comparisons that are of little value. Thus, the experimental research on the effectiveness of general procedures, such as free writing, is inconclusive.

Perhaps the most widely embraced body of research supporting general composing procedures has come from Graves (1979a, 1979b, 1979c, 1980, 1981a, 1981b, 1983) and his associates (Calkins, 1979, 1980a, 1980b, 1981; Kamler, 1980; Sowers, 1979; for a critical analysis, see Barrs, 1983; Hillocks, 1984, 1986a, 1986b; Smagorinsky, 1987). Graves, concerned that experimental research is "boring" (1979b, p. 76) and "smells of musty bookcases and crusty language" (p. 76), chose instead a case study method of examining Piagetian stages of writing development among elementary school children. Maintaining that "Research in education is not a science" (1979a, p. 917), he chose a more ethnographic approach that he believed would better examine the processes engaged in by writers and that would not simply rely on written products to illuminate the complexity of the writing process. Graves found that elementary school students could learn general procedures for topic selection (optimally focusing on personal experiences), text generation (i.e., writing a series of leads or possible opening lines), and unconstrained drafting of texts that follow many of the same principles of process advocated by Murray (1987) and Elbow (1973). Even though the studies by Graves have been criticized for their lack of internal consistency (i.e., they purport to be investigating developmental stages, yet student behavior is influenced deliberately by teacher interventions; Smagorinsky, 1987), they remain the most widely cited research base to support the benefits of general procedural composing knowledge.

The general knowledge position, then, has focused on both form and procedures, with the focuses greatly at odds. Murray, for instance, has offered the searing opinion that "The process of making meaning with written language cannot be understood by looking backward from a printed page. Process cannot be inferred from product any more than a pig can be inferred from a sausage" $(1980$, p.3). Yet the two focuses do share a common assumption that general knowledge is sufficient and that writers can transfer it spontaneously from situation to situation with relative ease. Murray maintains that the process approach to writing "can be adapted by our students to whatever writing tasks face them-the memo, the poem, the textbook, the speech, the consumer complaint, the job application, the story, the essay, the personal letter, the movie script, the accident report, the novel, the scientific paper" (1980, p. 20). While Murray has broadened the range of forms through which people express themselves from expository to other types of writing and has shifted the instructional emphasis from product to process, he asserts that knowledge of how to produce all types of compositions springs from the same source and applies broadly to them all.

For teachers, then, composition instruction emanating from the general knowledge position is concerned with providing students with a set of forms and/or procedures that will presumably serve them well as they move from topic to topic and from class to class. Those advocating a procedural emphasis tend to focus on methods for topic discovery, with the particular demands of different writing tasks seeming to fall into place as the composition unfolds, as, in Murray's words, "writing finds its own meaning" (1980, p. 20). This faith in general procedural knowledge is shared now by Warriner's English Composition and Grammar: Fifth Course, which in the 1988 version includes sections on general topic-finding procedures-such as, keeping 


\section{Smagorinsky and Smith}

a journal, brainstorming, clustering, and asking the five what-how questions-and advises students to " $\mathrm{Be}$ sure to go through each stage in the writing process: prewriting, writing a first draft, evaluating, revising, proofreading, and writing a final version" (p. 32). Through engagement in these procedures, the text assumes, students will be able to perform well regardless of the tasks and contexts in which they apply them.

\section{The Argument for Task-Specific Knowledge}

The view of writing as a general, all-purpose process is endorsed widely (Applebee, 1986). Yet, like the theory of general heuristics forwarded by Polya and others, the notion of general, transferable writing knowledge has come under question. The second position that we will review holds that composing knowledge is particular to different types of tasks and that, contrary to the notion that a general expository model or general set of procedures is sufficient, different types of tasks require different types of knowledge. Like the general knowledge position, the task-specific knowledge position is divided by the issue of whether the knowledge should concern form or procedures.

The argument for task-specific knowledge related to form is simply one that broadens the position originally taken by Warriner and Griffith (1977). Rather than holding that most people engage primarily in exposition, this position identifies a set of writing forms that people can learn and use whenever engaging in related types of tasks. This position has ancient roots that date back to the Greek academies of antiquity in which students memorized the orations of their masters. Today's version of this approach appears in the modern endorsement of the four classical forms of discourse: exposition, argumentation, description, and narration. Instruction in these forms presumes that each has a distinct set of traits that can be best learned by reading exemplary models, analyzing their characteristic elements, and then reproducing them in independent essays (Eschholz, 1980). The four classical forms often are expanded to include a variety of different text structures including the business letter, the film review, the comparison/contrast essay, the Shakespearean sonnet, and many others. Typically, however, the instructional approach is product centered, with students studying and imitating exemplary models.

The modern emphasis on process has resulted in dissatisfaction with productrelated instruction in task or form, and several theorists have suggested a procedural alternative to implementing task-related instruction. Chief among them have been Hillocks $(1975,1982,1984,1986 a, 1986 b, 1987)$ and his students and colleagues (Hillocks, Kahn, \& Johannessen, 1983; Hillocks, McCabe, \& McCampbell, 1971; Johannessen, Kahn, \& Walter, 1982; Kahn, Walter, \& Johannessen, 1984; McCann, 1989; Smagorinsky, 1986, 1989, 1991a, 1991b, 1992; Smagorinsky \& Gevinson, 1989; Smagorinsky, McCann, \& Kern, 1987; Smith, 1984; see also Applebee, 1986; Teich, 1987). Much of Hillocks's work has concerned instruction in essays that involve definition, a type of writing which, he argues, requires knowledge of procedures that are appropriate to the definition task but that are not necessarily helpful in producing writing with different task demands. Hillocks et al. (1983) describe certain "enabling strategies" (p. 276) for compositions involving the definition of abstract concepts: "1) to circumscribe the problem generally, 2) to compare examples in order to generate criteria which discriminate between the target concept and related but essentially different concepts, and 3 ) to generate examples which clarify the distinctions" (p. 276). 
These strategies are unique to the definition task; one would not employ them in analyzing the causes of the French Revolution. A teacher, these theorists argue, should not teach a few all-purpose strategies that enable writers to produce a definition, a business memo, and a short story; a teacher should conduct a task analysis (Hillocks et al., 1971; Johannessen et al., 1982) to identify the skills needed for successful performance in a particular writing task and to design activities that teach students the appropriate set of strategies. Hillocks concludes from his metaanalysis of exemplary experimental composition studies conducted from 1963-1983 $(1984,1986 \mathrm{a}, 1987)$ that an instructional focus that teaches writers task-specific composing procedures is the most effective of the focuses contrasted. Hillocks has labeled treatments that involve students in the inductive analysis of concrete materials in order to develop task-specific strategies an inquiry focus. He has argued strongly-too strongly, some feel (i.e., Durst, 1987; Newkirk, 1987)-that such instruction should supercede other approaches, particularly those that proceed from assumptions concerning the efficacy of general procedural knowledge.

Hillocks had argued previously (1982), in a manner similar to Murray's (1987), that writers in divergent disciplines engaged in scientific inquiry share certain basic strategies: "observing, describing, generalizing, comparing and contrasting (defining), hypothesizing, and testing generalizations" (p. 664). However, whereas Murray argues that knowledge of these skills is sufficient to guide all writing, Hillocks has contended that the complexity and demands of particular tasks require more specialized knowledge. Hillocks (1986b) has described writing tasks that involve processes quite different from the scientific process of inquiry. Writing a fable, for instance, requires writers to develop strategies for producing personification, narration, exaggeration, and so on suggesting that the two types of tasks involve quite different declarative and procedural knowledge of content and form. All of these tasks might indeed involve a voyage out and a voyage in, but the task-specific knowledge position asserts that the astute composer/pilot will board appropriate vehicles and employ particular procedures for negotiating the unique atmospheres and obstacles encountered in these vastly different environments.

Applebee (1986) argues that composition knowledge is task-specific, although he disagrees with some of Hillocks's distinctions between instructional modes and focuses. He argues that process approaches to teaching, although a preferable alternative to the prescriptive, product-centered methods of texts such as the older versions of English Grammar and Composition, have been badly underconceptualized, have been inadequate, and have been "embraced simplistically and naively" (p. 97). Applebee finds the reduction of process instruction to simple formulas regarding general stages of writing to be insufficient and misguided. He argues that, among the writers he has studied, "The choice of appropriate strategies was driven by the task at hand-not by a generalized conception of the 'writing process' that the writers used in all contexts" (p. 102). He continues,

Process activities are not appropriate for all writing tasks . . . and even when such activities are needed, different tasks will pose different problems and require in turn somewhat different writing processes. Some tasks require much planning and organizing before the writer can begin; some require careful editing before being shared with a critical audience; some involve sharing of familiar experiences within welllearned formats and require no further process supports at all. Indeed, the universe of writing tasks, both in and out of school, is large and diverse. Essay exams require 


\section{Smagorinsky and Smith}

one set of approaches, research papers another. The journalist dictating a latebreaking story over the telephone writes in one way, the short story writer in another. In part because studies of writing processes have ignored this diversity, processoriented instruction easily degenerates into an inappropriate and lockstep formula. If instruction is not conceptualized to make the link between process and product explicit and real, the approach is easily trivialized. Rather than suggesting a range of strategies for solving problems, process instruction will become just another series of practice exercises.

The task-specific knowledge position, then, argues for differentiated instruction, dependent on the particular demands of individual tasks. Advocates of this position would dispute Murray's (1980) notion that a writer can approach a poem and a memo in the same way and with the same procedures. Indeed, those who endorse this position would undoubtedly argue that even different types of poems-a sonnet, a free verse poem, a limerick, or virtually any other poetic type-would require unique knowledge, with each variation (i.e., different types of sonnets) requiring yet more specialized knowledge. Pedagogy based on the assumption that composing knowledge is task-specific requires an analysis of the particular knowledge required for each type of composition and explicit instruction in the appropriate set of procedures.

\section{The Argument for Community-Specific Knowledge}

The task-specific knowledge position asserts that particular tasks require particular types of knowledge. A third position holds that, even if one accepts the need for task-related knowledge, writers in different communities produce texts of similar structure in quite different ways because of the demands and customs of the particular communities in which they participate. Pauline Kael (1985) and Antonin Scalia (cited in Denniston, 1989), for instance, both write texts that rely on the generation of definitions. They produce them, however, for vastly different purposes and in decidedly different environments.

Film critic Pauline Kael's credibility depends on her ability to evaluate films according to a consistent set of standards, and hence she needs to convey in her reviews her definition of what constitutes quality in film. In her review of Roland Joffe's The Killing Fields, for instance, she offers the following:

\footnotetext{
Some of the episodes covering Pran's four years of slavery and escape attempts and beatings and his being tied to a tree and left for dead are [phonied up]; there are fictional episodes in which Pran, entrusted with the child of a disaffected Khmer Rouge official, tenderly carries the little boy in his arms over dangerous mountain passes, and the glossy piousness affects even the cinematography-it becomes blandly pictorial. . . . Yet the power of the images of urban death squads and the mass exodus from Phnom Penh stays with you. The great scenes are so impressive that the weak ones don't cancel out your emotions. (1985, p. 277)
}

A quality film, she implies, does not manipulate the action to develop characters and relationships or to toy with the viewer's emotions; she makes similar criticisms of Terms of Endearment and Penny Serenade for their bogus and calculated plot twists (p. 97). Good films, rather, portray the full emotional expressiveness of the characters through convincing action, leading the audience to a release of honest feelings. Through her establishment of her evaluative criteria and her consistent adherence to them, Kael has established herself as a credible judge of film. 
Antonin Scalia's arena, on the other hand, has been the court room, where he works to establish legal criteria for judging human behavior. In the following transcript, he is participating in the deliberations over whether or not the Supreme Court should judge the infamous Texas v. Johnson flag burning case. In questioning the prosecuting lawyer (Drew), Scalia and his fellow justices proceed as follows:

Stevens: You have not made an argument that there's anything unique about the flag.

Drew: Well, Your Honor, I disagree. The flag is the visible manifestation of over 200 years of history in this nation. The thirteen stripes represent the original thirteen colonies, and every state is represented on the field of blue by a star. It is unique. It is immediately recognizable to almost anyone who sees it.

Marshall: Suppose somebody burns an American flag with forty-eight stars.

Drew: I believe that that would be covered under this statute. That is clearly a past flag. Many people probably still own and display forty-eight star flags.

Scalia: But forty-seven wouldn't work because there was never a forty-seven star flag.

Drew: That would depend, Your Honor.

Scalia: All you have to do is take one star out of the flag and it's okay?

Drew: That would depend, Your Honor, on how flag is defined. Congress itself defines the flag: "The Stars and Stripes in any number which to an individual who looks at it without deliberation may be a flag." The flag behind you looks to me to be a flag, but I cannot count fifty stars on it.

Scalia: So you're saying forty-seven would be okay. I tend to think that's probably right. (Cited in Denniston, 1989, pp. 42-44)

Like Kael, Scalia engages in the same processes described by Hillocks et al. (1983) of circumscribing the problem generally and generating examples that discriminate between the target concept and closely related concepts. His ability to generate fine gradations in a series of examples is instrumental in defining what constitutes a flag; indeed, he and the other justices spend the bulk of the session generating problematic examples to come to agreement on the definitions of the key concepts of flag and desecration. Although he is not writing at this juncture of the hearings, he is undoubtedly engaging in a collaborative form of composing that will help shape the ultimate written decision of the court. His oral discourse here is much like the oral discourse of the students engaged in prewriting activities of the sort described by Hillocks et al. (1983).

The question is: Are Kael and Scalia involved in the same activity? Without a doubt, both are involved in the task-specific defining skills of generating criteria through the careful consideration of problematic examples. But would Pauline Kael make a good Supreme Court justice? And could Antonin Scalia manage a career as a film critic? In other words, even given the acquisition and mastery of the fundamental skills of the defining task, do they require further knowledge for particular applications of the procedures?

To consider these questions, we turn to different applications of what is generally known as argumentation. According to Toulmin (1958), all arguments include claims, data, warrants, propositions, qualifications, and rebuttals. Yet the form these elements take depends on the context in which one argues, both in terms of the conventions one follows and in terms of the particular declarative knowledge needed to persuade experts in the field to accept one's perspective. Most people would agree that declarative knowledge is essential to effective argumentation; Pauline Kael 


\section{Smagorinsky and Smith}

could not become a Supreme Court justice because she lacks an encyclopedic knowledge of legal precedent. Recent research has looked beyond declarative and procedural knowledge and investigated the importance of discourse conventions. An examination of argumentation as employed in two quite different fields, literary criticism and legal brief writing, will illustrate the different values that different communities place on particular argumentative traits.

Fahnestock and Secor (1991) have argued that literary criticism is a unique form of discourse, one which a purist might find deficient in terms of its implementation of argumentative structure:

Though literary arguments may seem flawed when viewed from a distance and by a field-independent standard, they can still be compelling to the audiences for whom they were intended. To identify the sources of their appeal, we must remember that these arguments exist in a particular field, a unique rhetorical situation; they are acts of communication directed at a special audience in a particular kind of forum, and as such they have their own characteristic procedures. Just as political oratory, pulpit homilies, and even advertising copy exploit a limited set of rhetorical possibilities, so also does literary criticism employ a definable repertoire of persuasive tactics to achieve communication in its well-defined environment. (p. 84)

A literary critic's effectiveness "depends not just on what is said but on the vehicle of its saying" (Fahnestock \& Secor, 1991, p. 91), with the metaphor serving as "the very vehicle by which the argument is framed in language" (p. 92). Literary argument also relies on the invocation of special topoi, including the use of paradox, which "may both serve the intellectual content of the argument and be an aesthetic end in itself, demonstrating the cleverness of the critic" (p. 88). Literary criticism, then, must be quite literary itself in order to persuade the literati of its merit. The purist reading literary criticism independent of its intended context might find it lacking because "literary arguments often do not make explicit certain structurally predictable elements- the definitions, causal linkages, comparisons which derive from the stases and common topoi of classical rhetoric" (p. 84). Yet the special literary topoi of literary critics "invoke the shared assumptions of the community of literary scholars, and at the same time create that community" (p. 84).

Stratman's analysis of legal brief writing (1990) suggests that a different community of writers employs argumentative structure in quite a different way, supporting Toulmin's (1958) view that different situations bring out nuances in the particular argumentative strategy. Stratman maintains that "legal writing is a distinct, unique kind of writing skill [that] can be taught" (p. 196). Stratman's findings about the writing of legal briefs-a particular form of argument-run counter to the widely held view of law schools that general practice in critical reasoning will result in good legal writing. As a consequence of their belief that students can transfer general thinking skills to their writing, law schools rarely give explicit instruction in legal composing.

Stratman (1990) finds this approach misguided, arguing that "What differentiates legal reasoning and argument from ordinary reasoning and argument are the unique rhetorical demands that structure the appellant-appellee (petitioner-respondent) relationships and the way courts may reconstitute opposing arguments in the context of this relationship" (p. 185). Appellate brief writers need to be able to make inferences about certain enduring dispositions common to both judges and their opposing lawyers, should be able to anticipate the ways in which judges and oppo- 
nents read through a brief, and should be able to simulate the ways in which judges and opponents interpret and integrate information from the brief. Thus, the task of successful legal brief writing requires specialized knowledge in audience characteristics that shape the content and form of the product, a necessary element of legal training that Stratman has found almost absent in law school instruction.

The studies on argumentation by Fahnestock and Secor (1991) and Stratman (1990) suggest the extraordinary complexity of successful writing and support the notion that particular tasks require not just general and task-specific declarative and procedural knowledge but also "knowledge that gives background and definition to [each discipline] - not only 'facts' but the terms of art, operational concepts, canons of relevance, patterns of association, characteristic argumentative gestures, and so on" (Colomb, 1988, p. 12). Those whose work seems to support the communityspecific knowledge position (i.e., Ackerman, 1991; Anson \& Forsberg, 1990; Bazerman \& Paradis, 1991; Berkenkotter, Huckin, \& Ackerman, 1988; Carter, 1990; Clark \& Doheny-Farina, 1990; Greene, in press; Herrington, 1985; Odell \& Goswami, 1985; Simons, 1989; Spivey, 1990; Witte, 1991, 1992) might agree that certain general thinking skills are essential to many different tasks. The question they might pose is: Can they be taught independently with the expectation that learners can spontaneously apply them to novel situations? Or should they be taught in the context of a specific type of problem that the learner needs to solve, one that involves the application of those skills within particular constraints and with specific task- and community-related knowledge?

Those who accept the community-specific knowledge position must also accept the necessity of conventional knowledge-that is, knowledge of the social or situational understandings that govern behavior under particular circumstances. According to this position, one may know generally how to drive and may know that general driving knowledge must be adjusted when one moves from a stick shift sports car to an automatic transmission recreational vehicle. Yet knowledge of how to drive also depends on knowledge of local customs: One operates a sports car one way on the Autobahn and another way on the Dan Ryan Expressway. Similarly, they would argue, one needs conventional knowledge when composing: the tone, sources of evidence, voice, and so on required to write for a practitioner-oriented journal are quite different from those needed to write for a research journal.

Teachers who adopt the community-specific knowledge position are faced with a daunting instructional problem. They must either instruct students to differentiate their writing in seemingly unlimited ways or be content with having limited influence on student writing. Perkins and Salomon (1988) offer some hope for teachers. They speak of the need for mindful attention to transfer-that is, the conscious and deliberate application of knowledge in contexts other than the one originally studied. They contend that teachers who "persistently and systematically . . . saturate the context of education with attention to transfer" (p. 29) will improve the likelihood that students will reapply knowledge when they shift domains. This saturation must be an integral part of the class structure rather than a tag at the end of a lesson; Salomon (1987) has found that most students are decidedly unmindful unless specifically and vigorously cued. Teachers who adopt the community-specific knowledge position and who aspire to retain their optimism regarding the range of their influence, then, must work hard at fostering a sense of consistent mindfulness in their students in adapting knowledge to new situations. 


\section{Literary Understanding}

\section{The Argument for General Knowledge}

As in composition, the view that reading, including reading literature, depends primarily on general knowledge still has much currency. Perkins and Salomon (1988), for instance, maintain that "surface characteristics of . . . new contexts strongly stimulate reading skills-text appears in front of one's eyes, so what else would one do but read it" (p. 27). To do so, readers apply what Irwin (1991) calls microprocesses, such as the chunking of groups of words into meaningful phrases. The question is whether this general knowledge is sufficient to enable one to read with understanding in different circumstances.

During the past 2 decades, radical changes in researchers' conceptions of reading have challenged the view that reading involves mastering a set of subskills that enable a reader to read any text. However, these new conceptions are also rooted in the belief in general knowledge, at least to some extent. In their recent review of reading research, Dole, Duffy, Roehler, and Pearson (1991) contend that the traditional view of reading "assumes a passive reader who has mastered a large number of subskills and automatically applies them to all texts" (p. 242). In contrast, they offer what they term the cognitive view, which "assumes an active reader who constructs meaning through the integration of existing and new knowledge and the flexible use of strategies to foster, monitor, regulate, and maintain comprehension"' (p. 242). Dole et al. criticize traditional skill instruction for connoting consistency, if not rigidity, and suggest that the goal of instruction should be to help students gain conscious control over a set of strategies that they can adapt to any text that they read. They offer five such strategies: determining importance, summarizing information, drawing inferences, generating questions, and monitoring comprehension. While these researchers emphasize that good readers adapt their strategies based on their purpose, task and text demands, and situational context, they identify and name the strategies that ought to stand at the center of the reading curriculum, a practice that indicates their faith in the importance of general procedural knowledge.

Even those researchers who begin with the belief that literary and nonliterary reading are qualitatively different experiences may display a belief in general knowledge. For example, although Langer $(1989,1990)$ does not speak of skills and strategies, she does describe important similarities between literary and nonliterary reading. She found that, in both kinds of reading, readers employed four stances: being out and stepping into an envisionment (i.e., the growing and changing sense a reader makes of a text), being in and moving through an envisionment, stepping back and rethinking what one knows, and stepping out and objectifying the experience. She argues that "the similarities in the process involved in responding across the different text types indicate that the four stances represent a range of meaningmaking options that underlie developing understandings in general-regardless of text type" (1989, p. 20).

The belief that "reading is reading" informs the approaches that many teachers take to instruct students in the study of literature. Scholes (1985) notes that professors of literature believe that they are not teachers of reading. They believe that because students have been taught to read in lower grades they are ready to read literature (or at least to hear about literary readings). This assumption also informs the approach taken by many high school texts. The 1989 edition of Scott, Foresman's Patterns in Literature (Farrell, Clapp, \& Kuehner, 1989) divides its objectives into six 
major skills areas: application of literary terms, reading skills, vocabulary skills, thinking skills, speaking and listening skills, and writing skills and technique. Although the list of literary terms covered in the book leads off their discussion of objectives, their presentation suggests the authors' confidence that skills and knowledge are transferred readily from one type of text to another. They cite recognizing cause and effect relationships as one of the reading skills students will learn, implying that this skill is similar across text types. They explain that students will practice such thinking skills as classifying and generalizing, implying that this general skill is transferable across disciplines. And even their statement of the literary terms addressed in the text suggests that they do not see reading different literary genres as requiring specialized skills or strategies. They distinguish literary terms from reading skills, implying that, while reading literature may require some specialized knowledge, it involves essentially the same processes as does any other kind of reading.

One implication of the belief in general reading skills is that literature instruction should help students develop the procedural knowledge that they need to read any new text. However, the distinction between the study of reading and literature that Scholes (1985) contends characterizes university curricula, a distinction that is in large measure replicated in the secondary schools, suggests that this implication has, in large measure, been rejected. Instead, the belief in general knowledge manifests itself in the belief that students of literature already have in place the skills and strategies they need to have meaningful transactions with literature. Interestingly, this belief has a number of its own instructional implications, implications often radically at odds with one another. Teachers holding such a belief in general knowledge might argue that, because students have the skills and strategies they need to read literature, teachers need only provide the occasion for exchange about the literature that the class reads together. Others might argue that it is a teacher's obligation to provide the knowledge that students undoubtedly do not have, knowledge of technical vocabulary, say, or declarative knowledge about author and text. Although recent research by Many and Wiseman (1992) suggests that these approaches need not be incompatible, as we noted in our discussion of composition, the belief in general knowledge is shared by theorists and teachers who seem to share little else.

Other researchers and theorists who have studied response to literature reject the idea that all reading is the same and seek instead to describe literary reading. However, while they may identify literary reading as a new domain, much of this research is marked by a belief in the applicability of general knowledge within that domain. For example, Rosenblatt $(1938,1978)$, certainly the most influential theorist on research in response to literature, draws a distinction between efferent and aesthetic reading. According to Rosenblatt, readers who adopt an efferent stance are concerned primarily with what they will take away from the reading, a concern that manifests itself in treating the text as information. Readers who adopt an aesthetic stance, on the other hand, are concerned with what they are living through while they are reading a text. Rosenblatt maintains that, although any text can be read with either an efferent or aesthetic stance, literature offers unique possibilities for aesthetic transactions. In drawing this distinction, Rosenblatt moves away from the reading is reading view. However, she does not distinguish what readers must do to have aesthetic transactions with different literary genres, and thus she still places her faith in general procedural knowledge for responding to literature. 


\section{Smagorinsky and Smith}

Hunt and Vipond's (1985, 1992; Vipond \& Hunt 1984) empirical investigations of literary reading, what they once called point-driven reading and now are calling dialogic reading, share this faith. Hunt and Vipond differ from Rosenblatt in that they posit three stances that distinguish dialogic from story-driven aesthetic readings. They characterize literary reading by identifying three types of strategies readers employ in such readings: coherence strategies, narrative surface strategies, and transactional strategies (Vipond \& Hunt, 1984). For Vipond and Hunt, this general procedural knowledge is applicable in reading any literary text.

Gevinson's (1990) study of four professors of English, thinking aloud as they read three stories, took a different tack to investigate literary understanding, but it shares the belief in general knowledge. Gevinson argues that literary understanding is a coherent concept, noting that despite differences in training, speciality, critical allegiance, age, and gender all of his readers seemed to share a conception of literary understanding very similar to the formalist theory of R. S. Crane. In a follow-up study (1991), he reanalyzed the protocols of his readers in an attempt to define expertise in reading literature. He identified five dimensions of expert behavior: stance; sense of the whole to be understood; declarative knowledge base; procedural knowledge base; and attitudes, habits and beliefs. He suggested that recognizing these dimensions of general literary knowledge can provide direction for curriculum planners.

Although a growing body of research makes the case for general knowledge by seeking to characterize literary reading, this research and theory has had less impact on curricula than did the broader general knowledge position that reading is essentially the same regardless of what is being read. Indeed, while some researchers are calling for more attention to the instructional implications of general literary knowledge (Probst, 1991; Squire, 1989), others are investigating the difficulties of bringing this research and theory into practice (Klages, 1992).

\section{The Argument for Task-Specific Knowledge}

No researcher or theorist would reject the idea that reading any text requires the application of a number of similar processes. However, some researchers and theorists emphasize the unique demands of certain kinds of literary texts. So, while they might accept Pressley, Goodchild, Fleet, Zajchowski, and Evans's (1989) argument on the importance of across-domain strategies, they place greater emphasis on what Pressley et al. would call task-limited strategies. That is, they argue that different kinds of literature invite readers to read in different ways.

Culler (1975), for example, argues that "texts have meanings for those who know how to read them-those who in their encounters with literature have assembled the conventions that are constitutive of literature as an institution and a means of communication" (p. 50). He argues further that "The task of literary theory or poetics, then, is to make explicit the procedures and conventions of reading, to offer a comprehensive theory of the ways in which we go about making sense of various kinds of texts" (1981, p. 125). That is, different kinds of literary texts place different demands on readers; to read these texts, then, readers must invoke the strategies and conventions appropriate to them.

Rabinowitz (1987) explores this argument in great depth. He explains that reading literature "is not even a logical consequence of knowledge of the linguistic system and its written signs. It is, rather, a separately learned, conventional activity" (p. 27). 
Rabinowitz argues that, in order to engage in an authorial reading, readers must have an understanding of appropriate literary conventions in place before they begin to read. He summarizes his view of reading by offering the metaphor of text as unassembled swing set. The mechanism is

a concrete thing, that when completed, offers opportunities for free play, but you have to assemble it first. It comes with rudimentary directions, but you have to know what the directions are, as well as how to perform basic tasks. It comes with its own materials, but you must have certain tools of your own at hand. Most important, the instructions are virtually meaningless unless you know beforehand what sort of object you are aiming at. (p. 38)

As his metaphor makes clear, according to Rabinowitz (1987), the genre of the text determines the nature of the instructions it offers and the conventions, strategies, or interpretive operations it requires to read it.

Rabinowitz (1987) does not claim that authorial reading is the only or even the best way to read. He does, however, argue that it is the sort of reading that most people (including academics) do and, more importantly, that it provides the basis for other sorts of reading, especially the kind of political reading that can make literature a source for social transformation. And, while he recognizes that the invitations that authors offer for conventional reading are socially constituted, he argues that, once readers have accepted an author's invitation, they discover meaning rather than create it.

Although little research has been conducted to evaluate particular approaches to teaching literature, several studies have investigated the effects of helping students develop task-specific knowledge. Smith (1989) found that giving students direct instruction in the interpretive strategies that Booth (1974) claims experienced readers use to understand irony significantly improved students' ability to understand ironic poetry, as measured by performance on an objective test and by responses to interview questions. In essence, Booth argues that authors alert readers to the presence of irony through five types of clues and that, once alerted, readers employ particular strategies to reconstruct ironic meanings. In Smith's study, students were taught the clues and strategies through the use of songs, short poems, and excerpts of poems before applying them independently to longer and more difficult poems. In addition to increasing students' understanding of ironic poetry, Hillocks (1989) found that such an approach resulted in substantially higher levels of engagement in classroom discussions than did a more traditional approach to teaching poetry. Further, Smith (1991, in press) has found that giving students direct instruction in the conventions experienced readers employ to understand unreliable narrators may help students become more active interpreters of meaning.

According to these theorists and researchers, having general knowledge does not guarantee that one can experience a meaningful transaction with a literary text. They therefore see the job of teachers of literature as determining what kinds of literature students need to know how to read, identifying strategies necessary for reading them, and designing instruction to teach the strategies. This position assumes that students will employ these strategies whenever the need arises, that once they have been taught strategies for, say, interpreting irony they will recognize and interpret irony in their subsequent independent reading.

Although the theorists and researchers who emphasize the importance of taskspecific knowledge believe that helping students develop that knowledge is a way to 


\section{Smagorinsky and Smith}

increase students' textual power, critics could object that such instruction in fact places unjustified limits on students' interpretations. In the first place, a belief in the existence of generalizable interpretive operations, even in particular domains, would result in instruction that would emphasize the conventional at the expense of the idiosyncratic. In the second place, instruction based on an analysis of the demands of particular kinds of texts necessarily places texts into genres. Teachers who use texts to teach strategies, then, preempt students from making their own judgments about the nature of the texts that they read. Perhaps most significantly, critics of this position might echo the concern of those who argue against emphasizing task-specific knowledge in composition instruction (i.e., Atwell, 1987) that: in planning instruction, teachers would necessarily privilege certain genres. Critics might contend that instruction would be based on what the teacher thinks is important rather than on what the students regard as important.

\section{The Argument for Community-Specific Knowledge}

Like those composition theorists and researchers who argue for the importance of task-specific knowledge, the theorists and researchers cited in the previous section argue that the form of the text places particular demands on its readers. Other theorists, most notably Stanley Fish, reject this argument. Unlike Rabinowitz (1987), who sees the formal features of texts as cuing the kind of reading necessary to do an authorially relevant interpretation, Fish (1980) believes that decisions about how to read are solely a function of the interpretive framework that the reader brings to the text:

Indeed, it is interpretive communities, rather than either the text or the reader, that produce meanings and are responsible for the emergence of formal features. Interpretive communities are made up of those who share interpretive strategies, not for reading but for writing texts, for constituting their properties. In other words these strategies exist prior to the act of reading and therefore determine the shape of what is read rather than, as is usually assumed, the other way around. (p. 14)

Fish's critique of Booth's (1974) A Rhetoric of Irony is instructive in elucidating his position. Whereas Booth argues that readers of irony are cued by the text to employ certain strategies, Fish (1983) claims that irony resides not in texts but rather in readers:

Irony, then, is neither the property of works, nor the creation of an unfettered imagination, but a way of reading, an interpretive strategy that produces the object of its attention, an object that is perspicuous to those who share or have been persuaded to share the same strategy. (p. 189)

That is, the clues are not in the text. Rather, the reader approaches the text having been persuaded to identify certain textual features as clues.

Fish's literary theory (1983) could find support in research on perspective taking in reading. This research (Anderson \& Pichert, 1978; Walczyk \& Hall, 1991) suggests that the perspective of the reader strongly influences what will be recalled from a story. For instance, Anderson and Pichert found that readers playing the role of a burglar were more likely to recall the kind and location of valuables in a house while those playing the role of prospective home buyers were more likely to recall that the house had spacious grounds. As Anderson and Pearson (1984) establish in their review of reading research, additional studies suggest that the perspective of the 
reader also affects the allocation of readers' attention. Fish's (1983) theory could also find support in studies of response to literature that identify distinct orientations that characterize individual reader's approaches to literature. The work of de Beaugrande (1985) and Dias (1987), for example, suggests that readers approach texts with a particular orientation already in place and that their orientation determines in large measure how they choose to read.

According to Fish (1980), the fundamental instructional implication of his theory is that teaching moves from the demonstration of interpretations "by facts that are independently specified" (p. 365) to persuasion that the presuppositions that have given rise to the facts are useful and valuable. Research suggests that teachers are indeed persuasive, with Applebee (1977) and Purves, Foshay, and Hansson (1973) finding that instruction has pronounced effects on the nature of students' response to literature.

Bleich (1978) suggests another approach consistent with Fish's (1980) view. He argues that, if students make texts of their responses by writing response statements, classes can use these texts to understand the impact of membership in various communities. Bleich contends that "to know anything at all is to have assigned a part of one's self to a group of others who claim to know the same thing" $(1978$, p. 296) and that the study of response statements allows classes "to identify the variety of viewpoints and pre-existing community memberships of both students and teachers" (1988, p. 318). For example, in Readings and Feelings (1975), Bleich analyzes responses of college freshmen to Vanity Fair to point out a common preoccupation with sex and marriage while, in The Double Perspective (1988), he provides several instances of responses that are affected by the gender of the reader.

Appleman (in press) offers another way that teachers can clarify the impact of community membership on interpretation. She calls for teaching students how to look through different critical lenses. She explains the results of teaching upper level, high school students to look at literature from four perspectives: reader-response, structuralist, Marxist, and feminist. Students' comments on how the course changed their reading are in line with Fish's (1980) argument. One wrote: "These literary theories, or critical lenses, will like change the meaning of the text to the reader" (Appleman, in press). Another wrote: "A book is not just black ink on paper-it's creation, feelings and images that you as the reader, reading through the lenses of Marxism, feminism, structuralism, and reader-response as well as others I don't know yet, make them out to be" (Appleman, in press). This student went on to suggest that the course be renamed "Through the Eyes of the Beholder."

Fish's (1980) notion of interpretive communities suggests that instruction should be centered on exploring the consequences of people's choosing to read in certain ways rather than on recognizing and accepting the invitation to read in conventional ways. Fish's own work, as well as the work of Bleich $(1978,1988)$ and Appleman (in press), suggests that teachers could make this exploration in several ways: by articulating the assumptions that guide their own reading, by helping students identify the communities to which they belong, and by helping students experience the impact that membership in different communities has on their reading. Critics (i.e., Booth, 1983) of this kind of instruction would argue that Fish's theory has unfortunate ethical consequences, for, by privileging the creative activity of the reader, it underestimates the benefits that attending to great imaginative works provides.

As in the case of composition, belief in community-specific knowledge forces teachers to recognize the limits of the consequences of their instruction. Teachers of 
literature who take this position believe that they are teaching $a$ way to read literature rather than the way to read literature. They also are participating in a long-standing and often rancorous debate on the nature of meaning and where it resides, a complete accounting of which extends far beyond the scope of this essay.

\section{Conclusion}

The debates about the specificity of knowledge that are raging in educational psychology raise issues that lie below the surface of discussions about how to investigate and teach composition and literary understanding. However, while the various antagonists in educational psychology have explicated their positions, these issues typically are unarticulated in discussions of literacy. Our primary purpose in identifying three positions regarding the specificity of knowledge-the case for general knowledge, the case for task-specific knowledge, and the case for community-specific knowledge-is to give voice to this silent debate. We believe that both researchers and teachers of literacy will benefit from articulating the principles that provide the underpinnings of their work.

We have found, in fact, that the distinctions have value as a heuristic. Our work on this review has caused us to reconsider our own teaching, especially our teaching in secondary schools. As our citations of our own work suggest, we have focused in our research and publications on how to develop task-specific knowledge, a focus that also dominated our high school teaching. Our students might have been better served had we considered more carefully the general and community-specific knowledge that they needed in addition to the task-specific knowledge we helped them develop. But like many teachers, although we did not declare allegiance to one of the positions in principle, we did so in practice. And the demands of our high schools' already crowded curricula gave us little reason or opportunity to think about what more we could do.

This is not to say that we believe the distinctions are absolute. In fact, we agree with those who have argued that drawing dichotomies (or trichotomies) serves rhetorical rather than theoretical and practical purposes and therefore have striven to take a conciliatory view in the dispute about the nature of knowledge in learning. Perkins and Salomon (1989) assert that "there are general cognitive skills; but they always function in contextualized ways" (p. 19). They caution against taking a winner-takeall stance in such disputes and argue in favor of a search for theoretical compatibility. Some researchers involved in basic (as opposed to instructional) research on reading and writing processes (i.e., Flower, 1987; Flower \& Hayes, 1980, 1981, 1984; Hayes \& Flower, 1980) have constructed models that include general processes, such as setting goals and drawing on prior knowledge. They view these processes, however, as subject to external factors, such as the task environment and the social context of learning. These environmental factors mediate if, when, and how a process is instantiated in reading or writing, leading the researchers ultimately to take a sociocognitive view of literacy (Flower, 1992).

However, though the positions may be compatible, we believe that the distinctions we have made are especially crucial for planners of curricula. Although basic research has examined general processes at all levels of age, schooling, and expertise, instructional research on the three positions suggests a curricular path (i.e., see, Carter, 1990). The general knowledge position is most widely substantiated at the elementary level, the task-specific position is best supported at the secondary and 
collegiate levels, and the community-specific position is most typically investigated at the upper levels of schooling and in the professions. And this makes sense. A base of general knowledge is necessary for learners to engage in specific writing and reading tasks. Both general and task-specific knowledge are likely to be prerequisite for membership in specialized discourse communities. We call this a curricular path, rather than a developmental one, because we see the acquisition of increasingly specialized knowledge as a function of instruction (whether formal or informal) rather than of age.

Our review, therefore, provides something of a paradox. It articulates distinctions among the positions taken by researchers, theorists, and teachers. But instead of resulting in more disputes, identifying these distinctions may help resolve arguments, at least as they are played out in the planning of curricula. Indeed, we believe that curricula and instruction that neglect any of the three types of knowledge we have identified neglect students as well.

\section{References}

Ackerman, J. (1991). Reading, writing, and knowing: The role of disciplinary knowledge in comprehension and composing. Research in the Teaching of English, 25(2), 133-177.

Adams, V. A. (1971). A study of the effects of two methods of teaching composition to twelfth graders. Unpublished doctoral dissertation, University of Illinois-Urbana, Champaign.

Alexander, P. A., Schallert, D. L., \& Hare, V. C. (1991). Coming to terms: How researchers in learning and literacy talk about knowledge. Review of Educational Research, 61, 315-343.

Alloway, E., Carrol, J., Emig, J., King, B., Marcotrigiano, I., Smith, J., \& Spicer, W. (1979). The New Jersey writing project. New Brunswick, NJ: Rutgers University, Educational Testing Service, New Jersey Public School Districts. (ERIC Document Reproduction Service No. ED 178 943)

Anderson, R. C., \& Pearson, P. D. (1984). A schema-theoretic view of basic processes in reading comprehension. In P. D. Pearson (Ed.), Handbook of reading research (pp. 255-291). New York: Longman.

Anderson, R. C., \& Pichert, J. W. (1978). Recall of previously unrecallable information following a shift in perspective. Journal of Verbal Learning and Verbal Behavior, 17, 1-12.

Anson, C. M. , \& Forsberg, L. L. (1990). Moving beyond the academic community: Transitional stages in professional writing. Written Communication, 7(2), 200-231.

Applebee, A. (1977). The elements of response to a literary work: What we have learned. Research in the Teaching of English, 11, 255-271.

Applebee, A. (1986). Problems in process approaches: Toward a reconceptualization of process instruction. In A. R. Petrosky \& D. Bartholomae (Eds.), The teaching of writing. 85th yearbook of the National Society for the Study of Education (pp. 95-113). Chicago: University of Chicago Press.

Appleman, D. (in press). Looking through critical lenses: Teaching literary theory to secondary students. In D. Bogdan \& S. Straw (Eds.), Constructive reading: Teaching beyond communication. Portsmouth, NH: Boynton/Cook.

Arthur, S. V. (1981). The effects of two writing treatments on the reading and writing of third graders. Dissertation Abstracts International, 41, 4278A.

Atwell, N. (1987). In the middle: Writing, reading and learning with adolescents. Portsmouth, NH: Heinemann, Boynton/Cook.

Baden, R. C. (1974). Freshman English: An action analysis of two models. Dissertation Abstracts International, 35, 392A.

Barrs, M. (1983). The new orthodoxy about writing: Confusing process and pedagogy. Language Arts, 60, 829-840. 


\section{Smagorinsky and Smith}

Bazerman, C., \& Paradis, J. (Eds.). (1991). Textual dynamics of the professions: Historical and contemporary studies of writing in professional communities. Madison, WI: University of Wisconsin Press.

Berkenkotter, C., Huckin, T. N., \& Ackerman, J. (1988). Conventions, conversations, and the writer: Case study of a student in a rhetoric Ph.D. program. Research in the Teaching of English, 22(1), 9-44.

Bleich, D. (1975). Readings and feelings. Urbana, IL: National Council of Teachers of English.

Bleich, D. (1978). Subjective criticism. Baltimore: Johns Hopkins University Press.

Bleich, D. (1988). The double perspective: Language, literacy and social relations. New York: Oxford University Press.

Booth, W. (1974). A rhetoric of irony. Chicago: University of Chicago Press.

Booth, W. (1983). A new strategy for establishing a truly democratic criticism. Daedalus, 112, 193-214.

Burns, H. L. (1980). Stimulating rhetorical invention in English composition through computer-assisted instruction. Dissertation Abstracts International, 40, 3734A. (ERIC Document Reproduction Service No. ED 188 245)

Calkins, L. M. (1979). Andrea learns to make writing hard. Language Arts, 56, 569-576.

Calkins, L. M. (1980a). Children learn the writer's craft. Language Arts, 57, 207-213.

Calkins, L. M. (1980b). Children's rewriting strategies. Research in the Teaching of English, 14, 331-341.

Calkins, L. M. (1981). Case study of a nine year old writer. In D. H. Graves (Ed.), A case study observing the development of primary children's composing, spelling, and motor behaviors during the writing process, final report (pp. 239-262). Durham: University of New Hampshire.

Carter, M. (1990). The idea of expertise: An exploration of cognitive and social dimensions of writing. College Composition and Communication, 41, 265-286.

Clark, G., \& Doheny-Farina, S. (1990). Public discourse and personal expression: A case study in theory-building. Written Communication, 7(4), 456-481.

Colomb, G. (1988, March). Where should students start writing in the disciplines? Paper presented at the Annual Meeting of the Conference on College Composition and Communication, St. Louis. (ERIC Document Reproduction Service No. ED 297 341)

Culler, J. (1975). Structuralist poetics. Ithaca, NY: Cornell University Press.

Culler, J. (1981). The pursuit of signs. Ithaca, NY: Cornell University Press.

Cummings, B. J. (1981). Prewriting, writing, rewriting: Teaching the composing process to basic writers at the college level. Dissertational Abstracts International, 42, 2465A.

Davis, K. (1979). Significant improvement in freshman composition as measured by impromptu essays: A large-scale experiment. Research in the Teaching of English, 13, 45-48.

de Beaugrande, R. (1985). Poetry and the ordinary reader: A study of immediate responses. Empirical Studies of the Arts, 3, 1-21.

Delaney, M. C. (1980). A comparison of a student-centered, free writing program with a teacher-centered rhetorical approach to teaching college composition. Dissertation Abstracts International, 41, 1985A.

Denniston, L. (1989, June). Where is the Rehnquist court headed? An oral argument in the first amendment. Harper's, pp. 35-48.

Dias, P. (1987). Making sense of poetry: Patterns in the process. Ottawa: Canadian Council of Teachers of English.

Dole, J., Duffy, G., Roehler, L., \& Pearson, P.D. (1991). Moving from the old to new: Research on reading comprehension instruction. Review of Educational Research, 62, 239-264.

Dreussi, R. M. E. (1976). A study of the effects of expressive writing on student attitudes and exposition. Dissertation Abstracts International, 37, 2806A.

Durst, R. K. (1987). Review of research on written composition: New directions for teaching. The Quarterly of the National Writing Project and the Center for the Study of Writing, 9(3), 23-25. 
Dutch, W. L. (1980). A comparison of the use of student-generated heuristics with the use of Larson-generated heuristics in a college classroom. Dissertation Abstracts International, 40, 6177A.

Ebbert, G. M. (1980). A comparison of three instructional approaches for teaching written composition: Pentadic, tagmemic, and control treatment. Dissertation Abstracts International, 41, 1985A.

Elbow, P. (1973). Writing without teachers. New York: Oxford University Press.

Elbow, P. (1981). Writing with power: Techniques for mastering the writing process. New York: Oxford University Press.

Emig, J. (1971). The composing processes of twelfth graders. Urbana, IL: National Council of Teachers of English.

Ennis, R. (1989). Critical thinking and subject specificity. Educational Researcher, 18(3), 4-10.

Ennis, R. (1990). The extent to which critical thinking is subject-specific: Further clarification. Educational Researcher, 19(4), 13-16.

Eschholz, P. A. (1980). The prose models approach: Using products in the process. In T. R. Donovan \& B. W. McClelland (Eds.), Eight approaches to teaching composition (pp. 21-36). Urbana, IL: National Council of Teachers of English.

Fahnestock, J., \& Secor, M. (1991). The rhetoric of literary criticism. In C. Bazerman \& J. Paradis (Eds.), Textual dynamics of the professions: Historical and contemporary studies of writing in professional communities (pp. 76-96). Madison: University of Wisconsin Press.

Farrell, E., Clapp, O., \& Kuehner, K. (1989). Patterns in literature. Glenview, IL: Scott, Foresman \& Co.

Fish, S. (1980). Is there a text in this class? Cambridge, MA: Harvard University Press.

Fish, S. (1983). Short people got no reason to live: Reading irony. Daedalus, 112, 175-192.

Flower, L. (1987). The role of task representation in reading to write (Tech. Rep. No. 6). Berkeley: University of California, Center for the Study of Writing, and Carnegie Mellon University.

Flower, L. (1992, April). Sociocultural perspectives on conceptual change. Paper presented at the Annual Meeting of the American Educational Research Association, San Francisco.

Flower, L., \& Hayes, J. R. (1980). The dynamics of composing: Making plans and juggling constraints. In L. Gregg \& E. Steinberg (Eds.), Cognitive processes in writing: An interdisciplinary approach (pp. 31-50). Hillsdale, NJ: Erlbaum.

Flower, L., \& Hayes, J. R. (1981). A cognitive process theory of writing. College Composition and Communication, 32, 365-387.

Flower, L., \& Hayes, J. R. (1984). The representation of meaning in writing. Written Communication, $1(1), 120-160$.

Fox, R. F. (1980). Treatment of writing apprehension and its effects on composition. Research in the Teaching of English, 14, 39-49.

Ganong, F. L. (1975). Teaching writing through the use of a program based on the work of Donald M. Murray. Dissertation Abstracts International, 35, 4125A.

Gauntlett, J. F. (1978). Project WRITE and its effect on the writing of high school students. Dissertation Abstracts International, 38, 7189A.

Gevinson, S. (1990). The shape of literary understanding: A study of four expert readers reading three short stories. Unpublished doctoral dissertation, University of Chicago.

Gevinson, S. (1991, April). Defining expertise in reading literature for understanding. Paper presented at the Annual Meeting of the American Educational Research Association, Chicago.

Graves, D. (1979a). Research doesn't have to be boring. Language Arts, 56, 76-80.

Graves, D. (1979b). What children show us about revision. Language Arts, 56, 312-319.

Graves, D. (1979c). Andrea learns to make writing hard. Language Arts, 56, 569-576.

Graves, D. (1980). A new look at writing research. Language Arts, 57, 913-919.

Graves, D. (1981a). A case study observing the development of primary children's composing, spelling, and motor behaviors during the writing process, final report. Durham: University of New Hampshire. 


\section{Smagorinsky and Smith}

Graves, D. (1981b). A new look at research on writing. In S. Haley-James (Ed.), Perspectives on writing in grade 1 (pp. 93-116). Urbana, IL: National Council of Teachers of English. Graves, D. (1983). Writing: Teachers and children at work. Exeter, NH: Heinemann.

Greene, S. (in press). Task, the construction of meaning, and authority in writing about history. In G. Leinhardt \& I. Beck (Eds.), The teaching and learning of history. Hillsdale, NJ: Erlbaum.

Hayes, J. R., \& Flower, L. (1980). Identifying the organization of writing processes. In L. Gregg \& E. Steinberg (Eds.), Cognitive processes in writing: An interdisciplinary approach (pp.3-30). Hillsdale, NJ: Erlbaum.

Herrington, A. (1985). Writing in academic setting: A study of the context of writing in two college chemical engineering courses. Research in the Teaching of English, 19, 331-362.

Hilgers, T. L. (1980). Training college composition students in the use of free-writing and problem-solving heuristics for rhetorical invention. Research in the Teaching of English, 14, 293-307.

Hillocks, G. (1975). Observing and writing. Urbana, IL: National Council of Teachers of English.

Hillocks, G. (1982, November). Inquiry and the composing process: Theory and research. College English, 659-673.

Hillocks, G. (1984). What works in teaching composition: A meta-analysis of experimental treatment studies. American Journal of Education, 93(1), 133-170.

Hillocks, G. (1986a). Research on written composition: New directions for teaching. Urbana, IL: ERIC, National Conference on Research in English.

Hillocks, G. (1986b). The writer's knowledge: Theory, research and implications for practice. In A. R. Petrosky \& D. Bartholomae (Eds.), The teaching of writing. 85th yearbook of the National Society for the Study of Education (pp. 71-94). Chicago: University of Chicago Press.

Hillocks, G. (1987, May). Synthesis of research on teaching writing. Educational Leadership, pp. 71-82.

Hillocks, G. (1989). Literary texts in classrooms. In P. W. Jackson \& S. Haroutunian-Gordon (Eds.), From Socrates to software: The teacher as text and the text as teacher. 88th yearbook of the National Society for the Study of Education (pp. 135-158). Chicago: University of Chicago Press.

Hillocks, G., Kahn, E., \& Johannessen, L. (1983). Teaching defining strategies as a mode on inquiry: Some effects on student writing. Research in the Teaching of English, 17, 275-284.

Hillocks, G., McCabe, B., \& McCampbell, J. (1971). The dynamics of English instruction. New York: Random House.

Hillocks, G., \& Smith, M. W. (1991). Grammar usage. In J. Flood, J. Jensen, D. Lapp, \& J. Squire (Eds.), Handbook of research on teaching the English language arts (pp. 591-603). New York: Macmillan.

Hirsch, E. D. (1987). Cultural literacy: What every American needs to know. Boston: Houghton Mifflin.

Hunt, R., \& Vipond, D. (1985). Crash-testing a transactional model of literary learning. Reader, 14, 23-29.

Hunt, R., \& Vipond, D. (1992). First, catch the rabbit: Methodological imperative and the dramatization of dialogic reading. In R. Beach, J. Green, M. Kamil, \& T. Shanahan (Eds.), Multidisciplinary perspectives on literacy research (pp. 69-89). Urbana, IL: National Conference on Research in English and National Council of Teachers of English.

Irwin, J. (1991). Teaching reading comprehension processes (2nd ed.). Englewood Cliffs, NJ: Prentice Hall.

Irwin, J., \& Doyle, M. A. (Eds.). (1992). Reading/writing connections: Learning from research. Newark, DE: International Reading Association.

Johannessen, L., Kahn, E., \& Walter, C. (1982). Designing and sequencing prewriting activities. Urbana, IL: National Council of Teachers of English. 
Kael, P. (1985). State of the art. New York: Dutton.

Kahn, E., Walter, C., \& Johannessen, L. (1984). Writing about literature. Urbana, IL: National Council of Teachers of English.

Kamler, B. (1980). One child, one teacher, one classroom: The story of one piece of writing. Language Arts, 57, 680-693.

Klages, M. (1992, April). Practicing theory: The limitations of reader response. Paper presented at the Annual Meeting of the American Educational Research Association, San Francisco.

Lamberg, W. J. (1974). Design and validation of instruction in question-directed narrative writing, developed through discrimination programming. Dissertation Abstracts International, 35, 2839A. (Eric Document Reproduction Service No. ED 097 689)

Langer, J. (1989). The process of understanding literature (Tech. Rep. No. 2.1). Albany: SUNY, Center for the Learning and Teaching of Literature.

Langer, J. (1990). The process of understanding: Reading for literary and informative purposes. Research in the Teaching of English, 24(3), 229-260.

Larson, R. L. (1968). Discovery through questioning: A plan for teaching rhetorical invention. College English, 30, 126-134.

Many, J., \& Wiseman, D. (1992, April). From anything goes to teacher controlled: The effectiveness of the middle ground in response-centered literature teaching. Paper presented at the Annual Meeting of the American Educational Research Association, San Francisco.

McCann, T. M. (1989). Student argumentative writing knowledge and ability at three grade levels. Research in the Teaching of English, 23(1), 62-76.

McPeck, J. (1990). Critical thinking and subject specificity: A reply to Ennis. Educational Researcher, 19(4), 10-12

Murray, D. (1980). Writing as process. In T. R. Donovan \& V. W. McClelland (Eds.), Eight approaches to teaching composition (pp. 3-20). Urbana, IL: National Council of Teachers of English.

Murray, D. (1987). Write to learn. New York: Holt, Rinehart \& Winston.

Newkirk, T. (1987). Review of research on written composition: New directions for teaching. Teachers College Record, 89(1), 155-157.

Norwood, M. C. D. (1974). Achievement as related to the ethnic origin of the student in an experience-centered approach to the teaching of freshman composition. Dissertation $A b$ stracts International, 35, 806A.

Odell, L. (1974). Measuring the effect of instruction in pre-writing. Research in the Teaching of English, 8, 228-240.

Odell, L. (1976, Summer/Autumn). Question-asking and the teaching of writing. The English Record, pp. 78-86.

Odell, L., \& Goswami, D. (Eds.). (1985). Writing in nonacademic settings. New York: Guilford.

Olson, M. C., \& DiStefano, P. (1976). Describing and testing the effectiveness of a contemporary model for in-service education in teaching composition. English Education, 12, 69-76.

Paris, S. G., Lipson, M. Y., \& Wixson, K. K. (1983). Becoming a strategic reader. Contemporary Educational Psychology, 8, 293-316.

Perkins, D., \& Salomon, G. (1988). Teaching for transfer. Educational Leadership, 46(1), 22-32.

Perkins, D., \& Salomon, G. (1989). Are cognitive skills context-bound? Educational Researcher, 18(1), 16-25.

Polya, G. (1954). Mathematics and plausible reasoning (Vols. 1-2). Princeton, NJ: Princeton University Press.

Polya, G. (1957). How to solve it: A new aspect of mathematical method (2nd ed.). Garden City, New York: Doubleday.

Pressley, M., Goodchild, F., Fleet, J., Zajchowski, R., \& Evans, E. (1989). The challenges of classroom strategy instruction. Elementary School Journal, 89, 301-342. 


\section{Smagorinsky and Smith}

Probst, R. (1991, February). Directions for research in response to literature. Paper presented at the Midwinter Conference of the National Council of Teachers of English Assembly on Research, Chicago.

Purves, A., Foshay, A., \& Hansson, G. (1973). Literature education in ten countries. New York: Wiley.

Rabinowitz, P. (1987). Before reading: Narrative conventions and the politics of interpretation. Ithaca, NY: Cornell University Press.

Reynolds, H. M. (1981). The design and testing of a focused and sequenced free writing approach to a first course in composition for two year college students. Dissertation Abstracts International, 42, 989A.

Rosenblatt, L. (1938). Literature as exploration. New York: Apple-Century.

Rosenblatt, L. (1978). The reader, the text, the poem: The transactional theory of the literary work. Carbondale, IL: Southern Illinois University Press.

Salomon, G. (1987, September). Beyond skill and knowledge: The role of mindfulness in learning and transfer. Invited address presented at the Second European Conference for Research on Learning and Instruction, Tubingen, Germany.

Scholes, R. (1985). Textual power. New Haven, CT: Yale University Press.

Simons, H. W. (Ed.). (1989). Rhetoric in the human sciences. Newbury Park, CA: Sage.

Smagorinsky, P. (1986). An apology for structured composition instruction. Written Communication, 3(1), 105-121.

Smagorinsky, P. (1987). Graves revisited: A look at the methods and conclusions of the New Hampshire study. Written Communication, 4(4), 331-342.

Smagorinsky, P. (1989). The effects of different types of knowledge on the writing process: A protocol analysis. Unpublished doctoral dissertation, University of Chicago.

Smagorinsky, P. (1991a). Expressions: Multiple intelligences in the English class. Urbana, IL: National Council of Teachers of English.

Smagorinsky, P. (1991b). The writer's knowledge and the writing process: A protocol analysis. Research in the Teaching of English, 25(3), 339-364.

Smagorinsky, P. (1992). How reading model essays affects writers. In J. W. Irwin \& M. A. E. Doyle, Reading/writing connections: Learning from research (pp. 35-44). Newark, DE: International Reading Association.

Smagorinsky, P., \& Gevinson, S. (1989). Fostering the reader's response: Rethinking the literature curriculum, grades 7-12. Palo Alto: Dale Seymour.

Smagorinsky, P., McCann, T., \& Kern, S. (1987). Explorations: Introductory activities for literature and composition, grades 7-12. Urbana, IL: National Council of Teachers of English.

Smith, M. W. (1984). Reducing writing apprehension. Urbana, IL: National Council of Teachers of English.

Smith, M. W. (1989). Teaching the interpretation of irony in poetry. Research in the Teaching of English, 23, 254-272.

Smith, M. W. (1991). Understanding unreliable narrators: Reading between the lines in the literature classroom. Urbana, IL: National Council of Teachers of English.

Smith, M. W. (in press). The effects of direct instruction in understanding unreliable narrators: An analysis of think-aloud protocols from ten ninth-grade readers. Journal of Educational Research.

Sowers, S. (1979). A six-year-old's writing process: The first half of first grade. Language Arts, $56,829-835$.

Spivey, N. N. (1990). Transforming texts: Constructive processes in reading and writing. Written Communication, 7, 256-287.

Squire, J. (1989, April). Research on reader response and the national literature initiative. Paper presented at the International Convention on Reading and Response, University of East Anglia, Norwich, England.

Stratman, J. (1990). The emergence of legal composition as a field of inquiry: Evaluating the prospects. Review of Educational Research, 60(2), 153-235. 
Teich, N. (1987). Transfer of writing skills: Implications of the theory of lateral and vertical transfer. Written Communication, 4(2), 193-208.

Toulmin, S. (1958). The uses of argument. Cambridge, England: Cambridge University Press.

Vipond, D., \& Hunt, R. (1984). Point-driven understanding: Pragmatic and cognitive dimensions of literary reading. Poetics, 13, 261-177.

Wagner, B. J., Zemelman, S., \& Malone-Trout, A. (1981). The Chicago Area Writing Project assessment. Elmhurst, IL: School District 205.

Walczyk, J., \& Hall, V. (1991). A developmental study of children's ability to adopt perspectives and find errors in text. Contemporary Educational Psychology, 16, 2-17.

Walker, J. P. (1974). A study of the comparative effectiveness of an experience-centered and a knowledge-centered method of teaching composition. Dissertation Abstracts International, $35,3704 \mathrm{~A}$.

Warriner, J. E. (1988). English composition and grammar (benchmark edition): Fifth course. Orlando, FL: Harcourt Brace Jovanovich.

Warriner, J. E., \& Griffith, F. (1977). English grammar and composition (heritage edition): Complete course. NY: Harcourt Brace Jovanovich.

Witte, S. (1991, April). Writing in context: A prolegomenon to a constructivist semiotic. Paper presented at the Annual Meeting of the American Educational Research Association, Chicago.

Witte, S. (1992). Context, text, intertext: Toward a constructivist semiotic of writing. Written Communication, 9(2), 237-308.

Witte, S., \& Faigley, L. (1981). A comparison of analytic and synthetic approaches to the teaching of college writing. Austin, TX: University of Texas, Department of English. (ERIC Document Reproduction Service No. ED 209 677)

Young, R. E., \& Koen, F. M. (1973). The tagmemic discovery procedure: An evaluation of its uses in the teaching of rhetoric. Ann Arbor: University of Michigan, Department of Humanities. (ERIC Document Reproduction Service No. ED 084 517)

\section{Authors}

PETER SMAGORINSKY is Assistant Professor, College of Education, University of Oklahoma, 820 Van Vleet Oval, Norman, OK 73019-0. He specializes in classroom literacy.

MICHAEL W. SMITH is Assistant Professor, Graduate School of Education, Rutgers University, New Brunswick, NJ 08903. He specializes in processes involved in reading literature and writing compositions and in considering how teachers can help students have more meaningful transactions with texts.

Received December 2, 1991 